\title{
Erratum to: Impacts of boreal hydroelectric reservoirs on seasonal climate and precipitation recycling as simulated by the CRCM5: a case study of the La Grande River watershed, Canada
}

\author{
C. Irambona ${ }^{1}$ - B. Music $^{2,3}$ • D. F. Nadeau ${ }^{3}$ - T. F. Mahdi ${ }^{1}$ I. B. Strachan ${ }^{4}$
}

Published online: 3 May 2017

(C) The Author(s) 2017. This article is an open access publication

\section{Erratum to: Theor Appl Climatol}

DOI 10.1007/s00704-016-2010-8

The article "Impacts of boreal hydroelectric reservoirs on seasonal climate and precipitation recycling as simulated by the CRCM5: a case study of the La Grande River watershed, Canada", written by C. Irambona, B. Music, D. F. Nadeau, T. F. Mahdi, and I. B. Strachan, was originally published electronically on the publisher's internet portal (currently SpringerLink) on 15 December 2016 without open access.

With the author(s)' decision to opt for Open Choice the copyright of the article changed on 22 April 2017 to (C) The Author(s) 2016 and the article is forthwith distributed under the terms of the Creative Commons Attribution 4.0
International License (http://creativecommons.org/licenses/ by/4.0/), which permits use, duplication, adaptation, distribution and reproduction in any medium or format, as long as you give appropriate credit to the original author(s) and the source, provide a link to the Creative Commons license, and indicate if changes were made.

The original article was corrected.

Open Access This article is distributed under the terms of the Creative Commons Attribution 4.0 International License (http:// creativecommons.org/licenses/by/4.0/), which permits unrestricted use, distribution, and reproduction in any medium, provided you give appropriate credit to the original author(s) and the source, provide a link to the Creative Commons license, and indicate if changes were made.

The online version of the original article can be found at http://dx. doi.org/10.1007/s00704-016-2010-8

D. F. Nadeau

daniel.nadeau@gci.ulaval.ca

1 Department of Civil, Geological and Mining Engineering, Polytechnique Montréal, Montréal, Canada

2 Ouranos Consortium on Regional Climatology and Adaptation to Climate Change, Montréal, Canada

3 Department of Civil and Water Engineering, Université Laval, Québec, Canada

4 Department of Natural Resource Sciences, McGill University, Ste. Anne de Bellevue, Québec, Canada 